\title{
ERRATUM
}

Joseph-Maria Gili • Pablo J. López-González

Jean Bouillon

\section{A new Antarctic association: the case of the hydroid Sarsia medelae (new sp.) associated with gorgonians}

Published online: 20 May 2006

(C) Springer-Verlag 2006

\section{Polar Biol (2005) DOI: 10.1007/s00300-005-0098-x}

In the above article the legend of Fig. 3 was incomplete.

Please find Fig. 3 with the complete legend below.

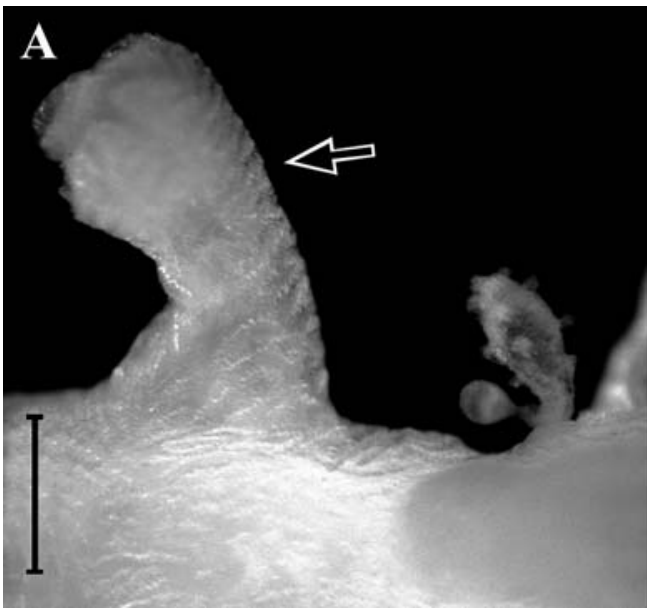

Fig. 3 Sarsia medelae n. sp. a MNA (1655), hydrant with gonophore near a polyp of the gorgonian Primnoisis sp. (open arrow) to observe the difference in size; b MNA (1655), portion of gorgonian coenenchyme decalcified and cleared to observe internal stolon

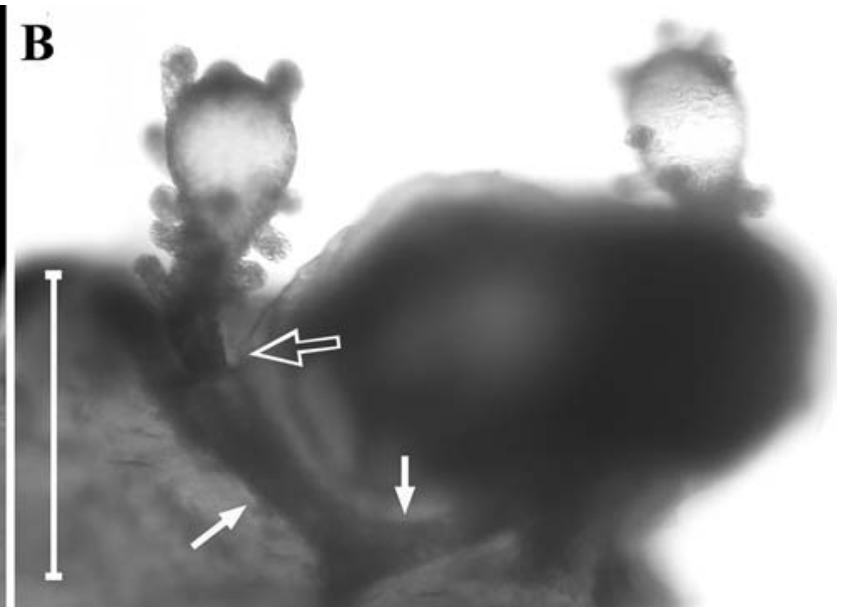

(solid arrows) within the gorgonian tissue, and the absence of pedicel between hydrant and stolon (open arrow). Scale bars: a and b $500 \mu \mathrm{m}$

The online version of the original article can be found at http:// dx.doi.org/10.1007/s00300-005-0098-x

J.-M. Gili $(\bowtie) \cdot$ J. Bouillon Institut de Ciències del Mar (CSIC),

Passeig Marítíum de la Barceloneta 37-49, 08003 Barcelona, Spain

E-mail: gili@icm.csis.es

P. J. López-González

Biodiversidad y Ecología de Invertebrados Marinos,

Departamento de Fisiología y Zoologia, Facultad de Biología, Universidad de Sevilla, Reina Mercedes 6, 41012 Sevilla, Spain 